\title{
Home gardens in the Eastern Cape Province, South Africa: A promising approach to enhance household food security and well-being
}

\author{
PELISA NGCABA, ALFRED MAROYI ${ }^{*}$ \\ Department of Botany, University of Fort Hare, Private Bag X1314, Alice 5700, South Africa. Tel./fax.: +27406022322, •email: amaroyi@ ufh.ac.za
}

Manuscript received: 6 August 2021. Revision accepted: 29 August 2021.

\begin{abstract}
Ngcaba P, Maroyi A. 2021. Home gardens in the Eastern Cape Province, South Africa: A promising approach to enhance household food security and well-being. Biodiversitas 22: 4045-4053. The current study is aimed at documenting the diversity and composition of food plants cultivated and maintained in home gardens; and also assessing their role at enhancing household food security and well-being in the Eastern Cape province, South Africa. This study was undertaken in six villages in the province, between June 2014 and March 2016. Information on socioeconomic and demographic characteristics of the respondents, home garden practices, food plants grown and maintained in home gardens were collected by means of questionnaires and guided field walks with 129 respondents. A total of 32 edible plants belonging to 27 genera and 18 families were recorded. The main uses of plants grown and managed in home gardens were edible fruits or seeds $(56.3 \%)$, leaves cooked as leafy vegetables $(28.1 \%)$, edible bulbs, roots and tubers $(21.9 \%)$, beverage, cereal, and culinary herb or spice (3.1\% each). The most preferred species were Zea mays (64.3\%), followed by Brassica oleracea (59.7\%), Solanum tuberosum (58.9\%), Spinacia oleracea (52.7\%), Allium cepa (51.9\%), Cucurbita moschata (44.2\%), Capsicum annuum (38.0\%), Cucurbita maxima (31.8\%) and Daucas carota (31.0\%). This study showed that home gardens can provide alternative sources of diverse and nutritious food to households, making home gardens an important agricultural resource for increasing food security in the province.
\end{abstract}

Keywords: Agricultural productivity, food security, home gardens, livelihoods, Eastern Cape province, South Africa

\section{INTRODUCTION}

According to Fernandes and Nair (1986) and Abdoellah et al. (2020), a home garden is defined as an intensively worked land-use agricultural system involving deliberate management of multipurpose plants and livestock within individual households. Similarly, Khanal et al. (2019) defined a home garden as a family managed microenvironment within the larger farming system often displaying high levels of species diversity, carefully tended and well delimited with fence or hedge from the neighboring farming fields but maintain a degree of exchange with the surrounding agricultural fields and natural ecosystems in terms of movement of species and genetic material. Mehari and Abera (2019) argued that there is no universal definition of the term home garden, and described it as an intensively worked land-use system with several plants and crops, in association with livestock managed around the family's homestead. Therefore, a home garden is a multipurpose farming system around a homestead where household members maintain diverse agricultural biodiversity. Agricultural biodiversity is regarded as a fundamental component of agricultural systems and it encompasses many types of biodiversity associated with agricultural systems, including the following (Thrupp, 2000; Heywood 2013; Allen et al. 2014; Maroyi 2020): genome, the essential genetic resource of all living organisms (i), wild edible plants and agricultural crops (ii), livestock and freshwater fish (iii), soil organisms which are important to soil fertility, composition, structure, health and quality (iv), naturally occurring insects, fungi, bacteria and virus which control insect diseases and pests of domesticated plants and animals (v), agro-ecosystem resources associated with nutrient stability, productivity and cycling (vi), and wild resources associated with natural landscapes and habitats which provide ecosystem functions and services to agriculture (vii).

Agricultural biodiversity as a concept also includes natural and man-made landscapes, habitats and species outside agricultural systems which benefit farming activities, agricultural processes and enhance ecosystem functions and services (Di Falco 2012). The different components of agricultural biodiversity are actively selected and managed, forming an evolving and sustainable agricultural farming system with indigenous knowledge associated with this land-use system transmitted from generation to generation. Mitchell and Hanstad (2004) cited by Galhena et al. (2013) listed the following five key features of home gardens: are located adjacent to the family's homestead (i), occupy a small space, averaging 0.5 hectares in extent (ii), contain a rich plant species diversity and variety of crops (iii), agricultural production is mostly supplementary to staple food supply done in main agricultural fields (iv), and are an agricultural system which the poor and marginalized households can easily enter into, helping themselves to reduce their vulnerability to hunger and other external shocks and risks (v).

Other researchers, for example, Adekunle (2013) and Gray et al. (2014) view a home garden as one of the grass- 
root household's most accessible and adaptable agricultural farming systems in developing countries, playing a vital role in ensuring food security to many households. Research by Algert et al. (2016) revealed that food security at the global, regional, national and individual levels is achieved when all individuals at all times, economic, social and physical access to safe, sufficient and nutritious food required to meet individual dietary needs and food preferences for a healthy and active life. Other general features that are associated with a home garden are yearround food production, minimized risks of agricultural failure due to high agrobiodiversity in home garden, increased agricultural productivity over time, high quality of labor, flexibility of agricultural productivity and several alternative agricultural production systems (Lowe et al. 2021). The farming systems categorized as home gardens are found in both rural, peri-urban and urban areas, with Mubarak and Suwardi (2020) arguing that a rural home garden is a component of an important household livelihood strategy or natural asset, if properly managed has potential to improve family's livelihoods and quality of life, reduce poverty and foster economic growth on a sustainable basis. Within this context, the value of home gardens in the Eastern Cape province was evaluated, assessing their contribution to food and nutrition, as well as social, economic, and environmental benefits required by local people.

\section{MATERIALS AND METHODS}

\section{Study area}

The Eastern Cape province is the second largest province in South Africa in size, covering an estimated area of about 169966 square kilometers (13.8\% of South Africa's land area) (www.gov.za/about-sa/south-africasprovinces). Large parts of the Eastern Cape province are made up of the former homelands of the Apartheid period, Ciskei and Transkei where many aspects of traditional culture are still practiced. The Apartheid government used the Bantu Authorities Act of 1951 which legalized the deportation of Black people into designated homelands such as Ciskei and Transkei. The black people were forcibly removed from white farms, peri-urban and urban areas to homelands such as Ciskei and Transkei. As a result of this act, Transkei was created in 1951 and Ciskei in 1961 (Hamann and Tuinder 2012; Sukeri et al. 2014; Cindi, 2018). The majority of areas in Ciskei and Transkei are still to a large degree characterized by poor infrastructure, low levels of economic activity, high population densities, high unemployment, pervasive chronic poverty, low capital investments and high levels of dependency on welfare (Ngcaba and Maroyi 2017; Thinyane and Maroyi 2019; Atyosi et al. 2019; Mdweshu and Maroyi 2020a,b). Research by Maroyi (2017a) showed that about $72 \%$ of the people in the Eastern Cape province live below the poverty line, which is above the national average of $60 \%$. The author argued that this pervasive chronic poverty is mainly due to the legacies of Apartheid where the Eastern Cape province inherited a largely corrupt and impoverished former Ciskei and Transkei homelands. Similarly, research by Westaway (2012) and Musemwa et al. (2015) showed that most households in the Eastern Cape province spend most of their monthly income on food and with overwhelming evidence that these households are characterized by growing food insecurity as measured by the quality, quantity and variety of food eaten and the number of meals consumed.

This study was undertaken in six villages; Ngxoto and Mpetsheni villages (study site 1, see Figure 1) in the Elundini Local Municipality; Mangathi and Colosa villages, study site 2 in the Mbhashe Local Municipality and KwaKhayalethu and Ngqele villages (study site 3, Figure 1) in Raymond Mhlaba Local Municipality. Study site 3 is situated in the former Ciskei homeland while study sites 1 and 2 are situated in the former Transkei homeland. Research by Maroyi (2017b) showed that annual rainfall ranges from $800 \mathrm{~mm}$ to $1200 \mathrm{~mm}$ while annual temperature ranges from $13^{\circ} \mathrm{C}$ to $22^{\circ} \mathrm{C}$ in Elundini Local Municipality (study site 1). The Mbhashe Local Municipality (study sites 2) is located in a climatic transition zone between the temperate south coast and the subtropical north coast of South Africa with average annual rainfall of $1069 \mathrm{~mm}$, average winter and summer temperatures of $21.5^{\circ} \mathrm{C}$ and $24^{\circ} \mathrm{C}$, respectively (Maroyi 2017a). Study sites 1 and 2 are located in rural areas with the dominant land use practice being grazing and with dryland crop production. Cultivated crops include beetroot (Beta vulgaris L.), cabbage (Brassica oleracea L.), carrots (Daucus carota L.), spinach (Spinacia oleracea L.), potatoes (Solanum tuberosum L.) and maize (Zea mays L.). Research by Hamann and Tuinder (2012) showed that at least $87 \%$ of the inhabitants in the Eastern Cape province are traditional Xhosaspeaking people who are highly dependent on natural resources for their livelihood needs. The vegetation of Mbhashe Local Municipality is described as a grasslandwoodland-forest mosaic characterized by a clear distinction between the grassland, woodland and forests because of the effects of clearing for cultivation and recurring fires (Popoola et al. 2020).

Jari and Fraser (2012) and Manyevere et al. (2014) described the climate of the study site 3 in the Raymond Mhlaba Local Municipality as mild characterized by annual rainfall ranging from $500 \mathrm{~mm}$ to $1000 \mathrm{~mm}$ with low to medium areas characterized by low to average annual rainfall while mountainous areas receiving the highest annual rainfall. Research by Maroyi (2017b) revealed that the Raymond Mhlaba Local Municipality has grassland, succulent thicket and Acacia thornveld dominated by Melinis nerviglumis (Franch.) Zizka, Vachellia karroo (Hayne) Banfi \& Galasso, Olea europaea L. ssp. africana (Mill.) P. S. Green, Aloe aborescens Mill., Eragrostis curvula (Schrad.) Nees, Aloe ferox Mill., Diospyros dichrophylla (Grand.) De Winter and Euphorbia spp. 


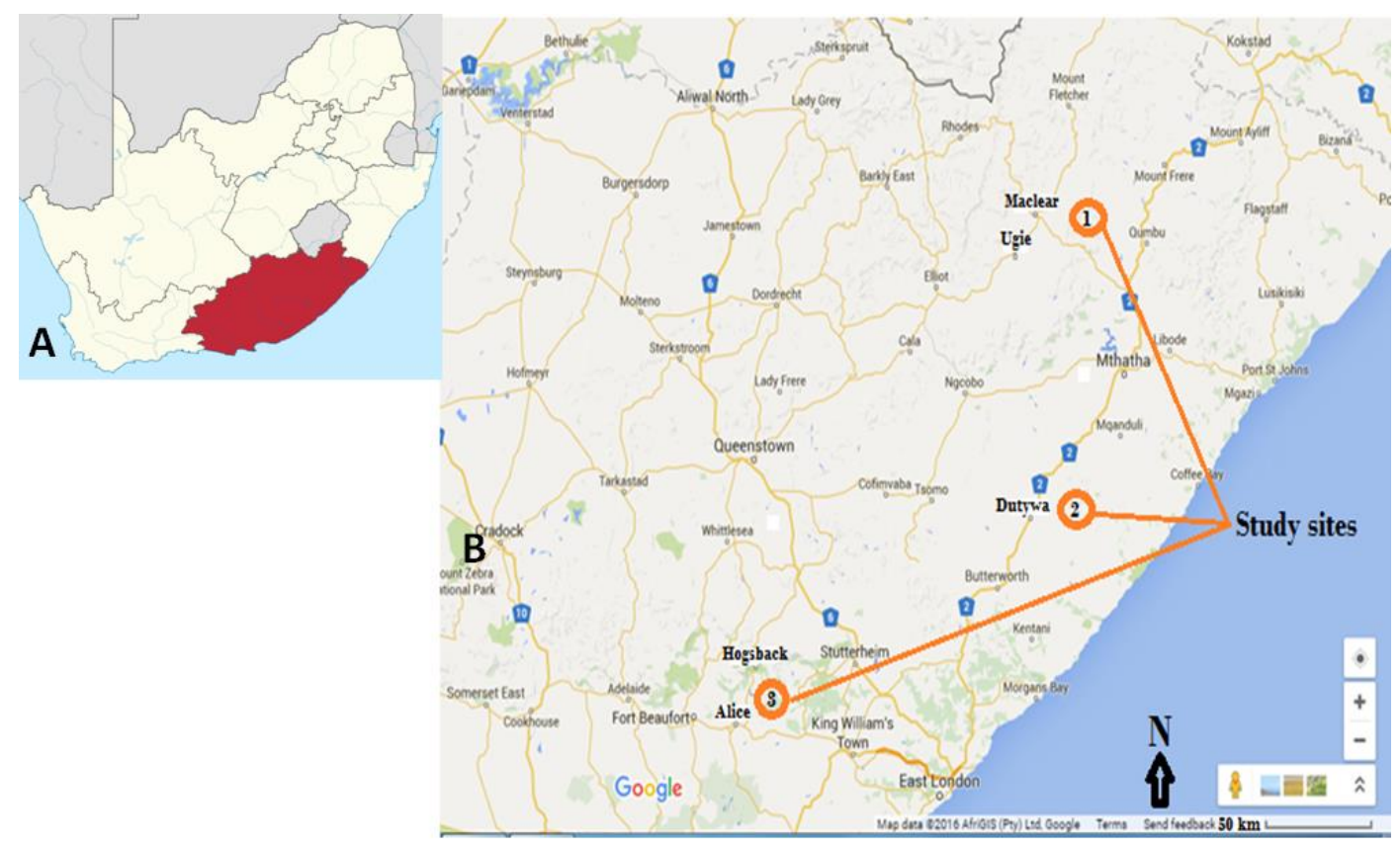

Figure 1. Map of South Africa (A) illustrating the geographical position of the study areas and B: detailed map of the study areas

\section{Data collection}

This study defines a home garden as a cropping area adjacent to a family dwelling, protected from animals by wooden fence, meshed wire, nets, barbed-wire fence, and sometimes by live fencing or hedge. The selected villages were Mpetsheni and Ngxoto (study site 1), Colosa and Mangathi (study site 2) both in the former Transkei homeland; and Ngqele and KwaKhayalethu (study site 3) in the former Ciskei homeland (Figure 1). One hundred and twenty-nine randomly selected individuals were interviewed between June 2014 and March 2016 (Table 1). The study utilized the participatory rural appraisal (PRA) methods (Cornwall and Pratt 2011; Menconi et al. 2017), emphasizing in-depth discussions with participants using open-ended questions in data gathering. Previous research by Cornwall and Pratt (2011) showed that structured and semi-structured interviews with local communities enable the researcher to understand much about the local peoples' culture, traditional knowledge and use of plant resources from the surrounding ecosystems. Recording such contextual details associated with home gardening activities will enhance understanding and establish the broader, contextual framework necessary to comprehend the complex relationships between people and the plant resources cultivated and managed in home gardens. Such research strategies of acquiring and sharing ethnobotanical knowledge is important in understanding the values and uses of plant resources managed in home gardens and documentation of such important plant species can be used as a vehicle for preserving the plant resources, indigenous knowledge and the cultural heritage of local households.

The nature of the current research required selection of research participants with the right information on home gardens, and therefore, a blend of purposive sampling and snowball sampling technique (Heckathorn 2011; Etikan et al. 2015; Waters 2015) was used for finding, selecting and inviting the participants. Home garden owners that were identified helped the researcher and research assistants to identify and locate other home garden owners for participation in the study. Structured and semi-structured interviews were conducted in isiXhosa language and participants were encouraged to sign the University of Fort Hare (MAR011) consent form after the researcher had explained the nature of the research work. The researchers also agreed to a working relationship with the community, including willingness to comply with indigenous or local and cultural governance systems, customs, laws, and protocols stipulated by the International Society of Ethnobiology (www.ethnobiology.net).

Information gathered during the interviews included the following: (i) the names of edible plants grown and maintained in home gardens, (ii) their uses and preparation protocols, (iii) perceptions of households on the importance of home garden plants in relation to food security, (iv) other benefits derived from cultivation of edible plants in home gardens, (v) and other uses of home garden plants such as medicine, shade, aesthetic, ornamental, fuelwood and income generation.

Other questions were employed for interviewing household heads to determine their home garden practices, various sources and quantities of income and food supply, socio-economic and demographic characteristics of participants, including household size, household head age and education and data on the constraints and challenges to home gardening activities. Results obtained through the interviews were complemented by personal observations, guided field walks and surveys with the participants. In terms of the questions on the practices and benefits of 
home gardening activities, the majority of questions were open-ended to avoid leading the participants to particular responses. During home garden surveys, home garden or plot size was measured, vernacular or local names of utilized plant species recorded and the period of the year when each plant species product is available was recorded, that is, rainy season, dry season, or all year round.

\section{RESULTS AND DISCUSSION}

\section{Description of home gardens, socio-economic and demographic characteristics of participants}

Table 1 summarises the home garden size, socioeconomic and demographic characteristics of the participants of this study. Home gardens in the study were well defined by mesh or barbed wire or wooden fence averaging $288 \mathrm{~m}^{2}$ in size (Table 1), which varied from village to village. Results obtained from an ANOVA analysis show that the differences in home garden size are significant in statistical terms (Probability $>F<0.001$ ). In previous research in Mangaung Metropolitan Municipality in the Free State province in South Africa, Nell et al (2000) found home garden size to be variable, located behind or in front of the house; and used mainly for crop production and household consumption.

Overall, we interviewed 129 participants and more than half $(67.4 \%)$ of participants were females. Close to half (45.8\%) were above 50 years, while $32.6 \%$ were below 40 years of age. More than half of the sample $(51.2 \%$ of participants) were married, $23.3 \%$ were divorced; $17.8 \%$ and $11.6 \%$ were widowed and single respectively (Table $1)$. The majority of families ( $72.8 \%$ of households) comprised between four and nine household members, while the number of children and adults per household ranged between 0 to 13 and one to six respectively (Table 1). More than half of the sample (64.4\% of participants) were educated up to primary level, while $21.7 \%$ of the sample were educated up to secondary level and $14.0 \%$ of the sample had attained tertiary education (Table 1). The majority of the participants $(66.7 \%)$ were unemployed, correlating with $62.8 \%$ surviving on less than R1 000.00 (US\$87.0) per month. Interviews with participants revealed different sources of income including the following (in descending order of importance): child support grant from government $(36.4 \%)$, remittances by family members who live and work elsewhere $(25.6 \%)$, old age pension grant from government $(13.2 \%)$, salary and wages $(8.5 \%)$, retirement pension $(6.5 \%)$ and income from farming activities (3.7\%). Results of the current study correlate with research findings obtained by Paumgarten et al. (2005) who revealed that the majority of the areas in the former homelands such as Ciskei and Transkei are characterized by a strong reliance on migrant remittances and state pensions, low economic activity, low levels of education and poor skills base. The majority of the participants in the current study $(49.6 \%)$ receive government grants, either child or old age grants.
Table 1. Home garden and household socio-economic and demographic characteristics of the study sample, $\mathrm{N}=129$

\begin{tabular}{|c|c|c|c|}
\hline & Mean & SD & Range \\
\hline Size of garden $\left(\mathrm{m}^{2}\right)$ & 288 & 120 & $90-2120$ \\
\hline $\begin{array}{l}\text { Socio-economic } \\
\text { variable }\end{array}$ & & No. & $\%$ \\
\hline \multirow[t]{2}{*}{ Gender } & Male & 42 & 32.6 \\
\hline & Female & 87 & 67.4 \\
\hline \multirow[t]{7}{*}{ Age (years) } & $<20$ & 5 & 3.9 \\
\hline & $20-29$ & 12 & 9.3 \\
\hline & $30-39$ & 25 & 19.4 \\
\hline & $40-49$ & 28 & 21.7 \\
\hline & $50-59$ & 30 & 23.3 \\
\hline & $60-69$ & 14 & 10.9 \\
\hline & $>70$ & 15 & 11.6 \\
\hline \multirow[t]{4}{*}{ Marital status } & Single & 15 & 11.6 \\
\hline & Married & 66 & 51.2 \\
\hline & Divorced & 30 & 23.3 \\
\hline & Widowed & 18 & 14.0 \\
\hline \multirow[t]{4}{*}{ Household size } & $1-3$ & 23 & 17.8 \\
\hline & $4-6$ & 55 & 42.6 \\
\hline & $7-9$ & 39 & 30.2 \\
\hline & $>10$ & 12 & 9.3 \\
\hline $\begin{array}{l}\text { Total number of } \\
\text { adults in a family }\end{array}$ & & & $4^{\mathrm{a}}(1-6)$ \\
\hline $\begin{array}{l}\text { Total number of } \\
\text { children in a family }\end{array}$ & & & $6^{a}(0-13)$ \\
\hline \multirow{4}{*}{$\begin{array}{l}\text { The highest level } \\
\text { of education }\end{array}$} & No formal education & 37 & 28.7 \\
\hline & Primary (grade 1-7) & 46 & 35.7 \\
\hline & Secondary (grade 8-12) & 28 & 21.7 \\
\hline & Tertiary & 18 & 14.0 \\
\hline \multirow[t]{4}{*}{ Occupation } & Unemployed & 86 & 66.7 \\
\hline & Employed & 19 & 14.7 \\
\hline & Self-employed & 15 & 11.6 \\
\hline & Other & 9 & 7.0 \\
\hline \multirow[t]{4}{*}{$\begin{array}{l}\text { Combined monthly } \\
\text { income }\end{array}$} & $\begin{array}{l}\text { Less than R1000 } \\
\text { (87.0 US\$) }\end{array}$ & 81 & 62.8 \\
\hline & $\begin{array}{l}\text { R1001-2000 (87.1- } \\
173.9 \text { US\$) }\end{array}$ & 23 & 17.8 \\
\hline & $>$ R2001 (174.0 US\$) & 13 & 10.1 \\
\hline & Not disclosed & 12 & 9.3 \\
\hline
\end{tabular}

Note: ${ }^{a}$ Values are medians unless otherwise indicated in table while figures in brackets are value ranges

\section{Diversity of food plants in home gardens}

The study recorded 32 food crop species (Table 2) in home gardens in the study sites in the Elundini, Mbhashe and in the Raymond Mhlaba Local Municipalities in the Eastern Cape province in South Africa. Almost all the recorded plant species in this study are well-known exotic species that are domesticated and cultivated in South Africa or a large proportion of these are agricultural weeds, except Centella coriacea Nannf., which is a South African endemic plant species confined to the KwaZulu Natal and the Eastern Cape provinces. Plant species cultivated in at least $30 \%$ of home gardens included (in descending order of importance): maize, Zea mays L. (cultivated in $64.3 \%$ of the home gardens), cabbage, Brassica oleracea L. (59.7\%), potato, Solanum tuberosum L. (58.9\%), spinach, Spinacia oleracea L. (52.7\%), onion, Allium cepa L., (51.9\%), butternut, Cucurbita moschata Duchesne ex Poir. (44.2\%), green pepper, Capsicum annuum L. (38.0\%), pumpkin, 
Cucurbita maxima Duchesne (31.8\%) and carrots, Daucus carota L. (31.0\%) (see Table 2). About three-quarters of the food plants $(72.3 \%)$ are from ten families, namely Amaranthaceae, Amaryllidaceae, Apiaceae, Asteraceae, Brassicaceae, Cucurbitaceae, Fabaceae, Rosaceae, Rutaceae and Solanaceae (Table 3). The other plant families were represented by one species for each. Among the main uses of plants grown and maintained in the home gardens in the study area were edible fruits or seeds $(56.3 \%)$, leaves cooked as leafy vegetables $(28.1 \%)$, edible bulbs, roots and tubers $(21.9 \%)$, beverage, cereal, and culinary herb or spice ( $3.1 \%$ each) (Table 2$)$. Therefore, home gardens in the study area play an important role as food production system, particularly in the provision of a variety of vegetables, fruits and to some extent as important sources of Zea mays (maize) grown as a cereal crop. The diverse mixture of vegetable and fruit crops are harvested at different times throughout the year (Table 4), enabling households to have food supply throughout the year.

Plant products of the majority of the useful species $(90.6 \%)$ recorded in this study were collected and consumed mainly during the rainy season (Table 4). About a third $(37.5 \%)$ of the edible species documented in this study were collected throughout the year (Table 4). The majority of these species $(25.0 \%)$ were vegetables, which included Allium cepa, Beta vulgaris, Brassica oleracea, Capsicum annuum, Daucus carota, Lactuca sativa, Lycopersicon esculentum and Spinacia oleracea. According to the participants, four species (12.5\%) fruit and flower throughout the year and therefore, and the fruits are available and collected for the greater part of the year. Such plants with edible fruits collected all year round included Citrus limon, Citrus sinensis, Musa X paradisiaca, and Persea americana (Table 4). The results recorded in this study are consistent with the idea that home gardens provide a year-round supply of many foods used by households and required to maintain sustainable food security (Freedman 2015). Other researchers such as Adekunle (2013) argue that engaging in home gardening activities help families against price shocks and improves the food security status of families since they will not be purchasing all their food requirements from the supermarkets.

\section{Motivations for home gardening}

This study revealed that supplementary agricultural crops such as vegetables and fruits are cultivated in home gardens and staple, major cash and food crops such as Zea mays are also widely grown. Nemudzudzanyi et al. (2009) obtained similar results, when the authors found that Zea mays were cultivated in $58 \%$ of the home gardens in Mbazwana and Esikwawini, KwaZulu-Natal province, South Africa. Zea mays was also a dominant cereal crop, playing an important role as staple diet of $38 \%$ of households in the North West province in South Africa (Molebatsi et al. 2010). Interviews with participants revealed that growing their own fruits and vegetables enables them to produce their own edible plants which helps them to reduce their vulnerability to hunger. About a quarter of the participants $(25.6 \%)$ argued that food plants produced from home gardens enable households to feed themselves without necessarily buying them from food markets. A small proportion of the participants $(5.4 \%)$ gave some home garden produce particularly fruits and vegetables to neighbors and relatives. This exchange of home garden products between households is an important socio-economic benefit of home gardening, as it allows households to share indigenous knowledge associated with home gardening activities, thus strengthening family relationships and bonds (Figure 2). These observations made in the study area are consistent with the results obtained by Musvoto and Campbell (1995) who found that households consumed nearly half of the mangoes produced in home gardens in Zimbabwe and the remainder were given to relatives and school children or sold in local informal markets.

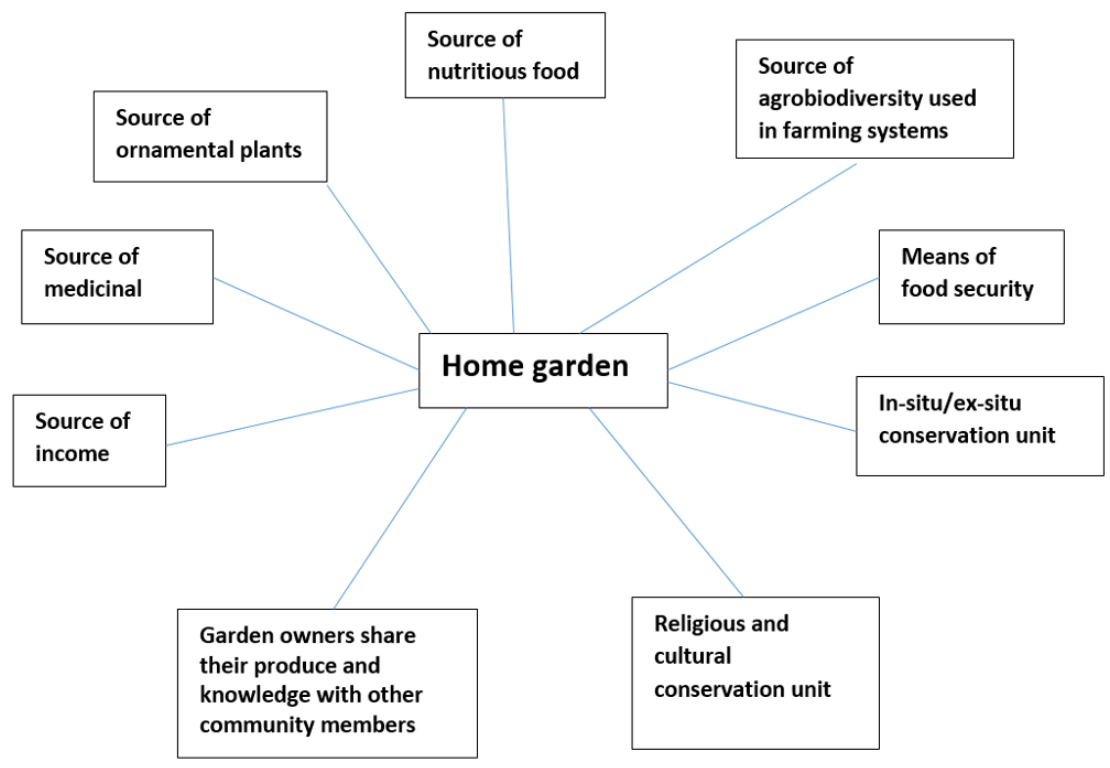

Figure 2. Conceptual model of how home garden produce is utilized in the Eastern Cape province, South Africa 
Table 2. Plant species recorded from home gardens in the study area arranged in descending order of importance

\begin{tabular}{|c|c|c|c|}
\hline Scientific name & $\begin{array}{l}\text { Xhosa }(X) \text { and } \\
\text { English }(E) \text { names }\end{array}$ & Plant use category & $\begin{array}{l}\% \text { of home } \\
\text { gardens }\end{array}$ \\
\hline Zea mays L. & Maize (E), umbone (X) & $\begin{array}{l}\text { Used as beverage and cereal: seed pounded into samp or green mealies } \\
\text { roasted or cooked. Unshelled fruits and shelled seeds were preserved for } \\
\text { later use. }\end{array}$ & 64.3 \\
\hline Brassica oleracea $\mathrm{L}$. & $\begin{array}{l}\text { Cabbage (E), } \\
\text { ikhaphetshu (X) }\end{array}$ & $\begin{array}{l}\text { Leaves cooked as vegetables or made into salad. Cabbage head } \\
\text { preserved for later use }\end{array}$ & 59.7 \\
\hline Solanum tuberosum $\mathrm{L}$. & $\begin{array}{l}\text { Amazambane }(X) \\
\text { potato }(E)\end{array}$ & $\begin{array}{l}\text { Tubers cooked, baked, fried, mashed and made into salad. Tubers } \\
\text { preserved for later use }\end{array}$ & 58.9 \\
\hline Spinacia oleracea $\mathrm{L}$. & Imifuno $(X)$, spinach $(E)$ & Leaves cooked as vegetables or made into salad & 52.7 \\
\hline Allium cepa $\mathrm{L}$. & Itswele $(\mathrm{X})$, onion $(\mathrm{E})$ & Tubers added to vegetables, meat and salad. Tubers preserved for later use & 51.9 \\
\hline $\begin{array}{l}\text { Cucurbita moschata } \\
\text { Duchesne ex Poir. }\end{array}$ & $\begin{array}{l}\text { Butternut (E), ithanga } \\
(\mathrm{X})\end{array}$ & $\begin{array}{l}\text { Fruit is roasted or mashed; young shoots, flowers and fruits cooked as } \\
\text { vegetables. Fruits preserved for later use }\end{array}$ & 44.2 \\
\hline Capsicum аппиит $\mathrm{L}$. & Itshilisi (X), pepper (E) & $\begin{array}{l}\text { Fruit is cooked, mixed with other vegetables or meat. Fruits preserved } \\
\text { for later use }\end{array}$ & 38.0 \\
\hline $\begin{array}{l}\text { Cucurbita maxima } \\
\text { Duchesne }\end{array}$ & $\begin{array}{l}\text { Ithanga }(\mathrm{X}) \text {, pumpkin } \\
\text { (E) }\end{array}$ & $\begin{array}{l}\text { Fruit is roasted or mashed; young shoots, flowers and fruits are cooked } \\
\text { as vegetables. Fruits preserved for later use }\end{array}$ & 31.8 \\
\hline Daucus carota $\mathrm{L}$. & $\begin{array}{l}\text { Carrots (E), umnqathi } \\
(\mathrm{X})\end{array}$ & $\begin{array}{l}\text { Root eaten raw, cooked, mixed with other vegetables or meat. Root } \\
\text { preserved for later use }\end{array}$ & 31.0 \\
\hline Prunus persica $($ L.) Batsch & Ipesika $(X)$, peach $(E)$ & Fruits edible, preserved for later use & 20.2 \\
\hline Citrus sinensis (L.) Osbeck & kIorenji $(X)$, orange $(E)$ & Fruits edible, preserved for later use & 17.8 \\
\hline $\begin{array}{l}\text { Lycopersicon } \\
\text { esculentum Mill. }\end{array}$ & Tomato $(\mathrm{E})$, tumata $(\mathrm{X})$ & $\begin{array}{l}\text { Fruit eaten raw in salad or cooked, mixed with other vegetables or meat. } \\
\text { Fruits preserved for later use }\end{array}$ & 17.8 \\
\hline Phaseolus vulgaris $\mathrm{L}$. & Bean (E), mbotyi (X) & $\begin{array}{l}\text { Green pods and dry seeds boiled as vegetables and can be mixed with } \\
\text { other vegetables or meat. Dry seeds preserved for later use }\end{array}$ & 16.3 \\
\hline Beta vulgaris $\mathrm{L}$. & Beetroot $(\mathrm{E})$ & $\begin{array}{l}\text { Root cooked and eaten on their own or made into salad. Root preserved } \\
\text { for later use }\end{array}$ & 14.0 \\
\hline Psidium guajava $\mathrm{L}$. & Guava (E), ugwava (X) & Fruits edible, preserved for later use. Also used as herbal medicine. & 14.0 \\
\hline Lactuca sativa $\mathrm{L}$. & Ilethasi $(\mathrm{X})$, lettuce $(\mathrm{E})$ & $\begin{array}{l}\text { Leaves eaten raw or made into salad. Vegetable head preserved for later } \\
\text { use }\end{array}$ & 13.2 \\
\hline Musa X paradisiaca $\mathrm{L}$. & Banana (E) & Fruits edible, preserved for later use & 12.4 \\
\hline $\begin{array}{l}\text { Citrus limon (L.) Burm. } \\
\text { f. }\end{array}$ & Lamuni (X), lemon (E) & Fruits edible and preserved for later use & 10.1 \\
\hline $\begin{array}{l}\text { Ipomoea batatus (L.) } \\
\text { Lam. }\end{array}$ & $\begin{array}{l}\text { Bhatata }(X) \text {, sweet } \\
\text { potatoes }(\mathrm{E})\end{array}$ & Tubers cooked and eaten on their own. Tubers preserved for later use & 10.1 \\
\hline Pisum sativum $\mathrm{L}$. & Erityisi (X), pea (E) & $\begin{array}{l}\text { Young seeds boiled as vegetables and can be mixed with other } \\
\text { vegetables or meat. }\end{array}$ & 10.1 \\
\hline $\begin{array}{l}\text { Opuntia ficus-indica } \\
\text { Mill. }\end{array}$ & $\begin{array}{l}\text { Itolofiya }(X) \text {, prickly } \\
\text { pearr }(E)\end{array}$ & $\begin{array}{l}\text { Fruits edible and preserved for later use. Also used as hedge, } \\
\text { ornamental and herbal medicine }\end{array}$ & 9.3 \\
\hline Brassica rapa $\mathrm{L}$. & Turnip (E) & $\begin{array}{l}\text { Leaves and roots cooked as vegetables. Leaves and roots preserved for } \\
\text { later use }\end{array}$ & 7.8 \\
\hline Persea americana Mill. & Avocado (E) & Fruits edible, preserved for later use & 7.8 \\
\hline Prunus armeniaca $\mathrm{L}$. & Apricot $(\mathrm{E})$ & Fruits edible, preserved for later use & 3.9 \\
\hline Amaranthus hybridus L. & $\begin{array}{l}\text { Nomdlomboyi (X), } \\
\text { Pigweed (E) }\end{array}$ & Leafy vegetable & 3.1 \\
\hline Bidens pilosa $\mathrm{L}$. & $\begin{array}{l}\text { Umhlabangulo (X), } \\
\text { Black jack (E) }\end{array}$ & Leafy vegetable & 3.1 \\
\hline Allium sativum $\mathrm{L}$. & Garlic (E) & Edible bulbs & 3.1 \\
\hline $\begin{array}{l}\text { Centella coriacea } \\
\text { Nannf. }\end{array}$ & Unongotyozana $(\mathrm{X})$ & Leafy vegetable and herbal medicine & 3.1 \\
\hline Malus domestica Borkh. & Apile $(X)$, apple (E) & Fruits edible, preserved for later use & 3.1 \\
\hline Vitis vinifera $\mathrm{L}$. & Umdiliya $(\mathrm{X})$, grapes $(\mathrm{E})$ & Fruits edible fruits & 3.1 \\
\hline Sonchus asper (L.) Hill & $\begin{array}{l}\text { Irwabe }(X) \text {, spiny } \\
\text { sowthistle }(E)\end{array}$ & Leaf vegetable and herbal medicine & 1.6 \\
\hline Ficus carica $\mathrm{L}$. & Fig $(\mathrm{E})$, ikwiwane $(\mathrm{X})$ & Fruits edible, preserved for later use. Also used as herbal medicine & 1.6 \\
\hline
\end{tabular}

The open-ended questions, "What are the benefits of having a garden? and What criteria is used to identify plant species suitable for the home garden? generated several responses summarized in Table 5. The most important criteria used by participants in selecting plant species that are suitable to be introduced or grown in home gardens was whether they are edible or have edible parts or not. All the participants mentioned provision of food to the household as their main criteria and $13.2 \%$ mentioned the cash value of the home garden species. The value of home gardens for food production and household livelihoods needs was ubiquitously perceived, with all respondents reporting their positive contribution towards household food provision (Table 5). According to the participants, the majority of 
households acquire their food from supermarkets and other food outlets. More than three-quarters of the participants $(83.7 \%)$ said home gardens produce is insufficient for the majority of households, and therefore provides an alternative source of food to their households (Table 5). It is noteworthy to mention some participants $(2.3 \%)$ who argued that home garden produce is valuable for the family's health as they contain less chemicals compared to commercially produced food products. Other participants $(10.1 \%)$ are of the view that the importance of home gardening has decreased over the years (Table 5). The diversity of edible plants associated with home gardens is appreciated by close to a quarter of the participants $(20.2 \%)$, with a similar proportion of participants $(24.0 \%)$ arguing that households with their own food produced from home gardens tend to reduce food purchases from supermarkets or other food markets. Previous research by Van Averbeke and Khosa (2007) revealed that the low food self-sufficient households spent $83 \%$ of their total expenditure on buying food, while the high food selfsufficient households spent about $57 \%$ of their total household expenditure on food.

Apart from being important sources of food plants, home gardens in the study area have other uses associated with cultural, societal and aesthetical importance (Figure 2 ). Some of the plant species documented in this study serve more than one use category (Table 2), and such species include Centella coriacea, Ficus carica, Psidium guajava and Sonchus asper (also used as herbal medicines) and Opuntia ficus-indica (hedge, herbal medicine, ornamental). A trend that has also been observed in Zimbabwean home gardens where Opuntia ficus-indica is grown as a vegetable, ornamental plant and herbal medicine; while Psidium guajava is cultivated for its edible fruits and as herbal medicine (Maroyi 2009).

The socio-demographic survey (Table 1) showed that the majority of families in the study area depend on government assistance in the form of old-age pension grants, child support grants, and other forms of income such as remittances by family members who live and work elsewhere which they use to buy food and other household essentials. Therefore, although home gardens in the Eastern Cape province are an important source of food plants, most families do not sorely depend on them for household food requirements. Home garden produce is generally used to supplement household food acquired from supermarkets, shops and other food markets.

Table 3. Different plant families with at least two species of edible plants in the study area

\begin{tabular}{lcc}
\hline Family & No. of species & Proportion (\%) \\
\hline Amaranthaceae & 3 & 9.4 \\
Rosaceae & 3 & 9.4 \\
Solanaceae & 3 & 9.4 \\
Amaranthaceae & 2 & 6.3 \\
Amaryllidaceae & 2 & 6.3 \\
Apiaceae & 2 & 6.3 \\
Brassicaceae & 2 & 6.3 \\
Cucurbitaceae & 2 & 6.3 \\
Fabaceae sensu lato & 2 & 6.3 \\
Rutaceae & 2 & 6.3 \\
\hline
\end{tabular}

Table 4. Seasonality of home garden plants in the Eastern Cape province as derived from PRA exercises with different household heads

\begin{tabular}{|c|c|c|c|}
\hline Species and English name & $\begin{array}{l}\text { Rainy } \\
\text { season }\end{array}$ & $\begin{array}{c}\text { Dry } \\
\text { season }\end{array}$ & $\begin{array}{c}\text { All year } \\
\text { round }\end{array}$ \\
\hline Allium cepa (onion) & $\sqrt{ }$ & $\sqrt{ }$ & $\sqrt{ }$ \\
\hline Amaranthus hybridus (pigweed) & $\sqrt{ }$ & & \\
\hline Beta vulgaris (beetroot) & $\sqrt{ }$ & $\sqrt{ }$ & $\sqrt{ }$ \\
\hline Bidens pilosa (black jack) & $\sqrt{ }$ & & \\
\hline Brassica oleracea (cabbage) & $\sqrt{ }$ & $\sqrt{ }$ & $\sqrt{ }$ \\
\hline Brassica rapa (turnip) & & $\sqrt{ }$ & \\
\hline Capsicum annum (pepper) & $\sqrt{ }$ & $\sqrt{ }$ & $\sqrt{ }$ \\
\hline Centella coriace & $\sqrt{ }$ & & \\
\hline Citrus limon (lemon) & $\sqrt{ }$ & $\sqrt{ }$ & $\sqrt{ }$ \\
\hline Citrus sinensis (orange) & $\sqrt{ }$ & $\sqrt{ }$ & $\sqrt{ }$ \\
\hline Cucurbita maxima (pumpkin) & $\sqrt{ }$ & $\sqrt{ }$ & \\
\hline Cucubita moschata (butternut) & $\sqrt{ }$ & & \\
\hline Daucus carota (carrots) & $\sqrt{ }$ & $\sqrt{ }$ & $\sqrt{ }$ \\
\hline Ficus carica (fig) & $\sqrt{ }$ & $\sqrt{ }$ & \\
\hline Ipomoea batatas (sweet potatoes) & $\sqrt{ }$ & $\sqrt{ }$ & \\
\hline Lactuca sativum (letuce) & $\sqrt{ }$ & $\sqrt{ }$ & $\sqrt{ }$ \\
\hline Lycopersicon esculenta (tomatoes) & $\sqrt{ }$ & $\sqrt{ }$ & $\sqrt{ }$ \\
\hline Malus domestica (apple) & $\sqrt{ }$ & $\sqrt{ }$ & \\
\hline Musa X paradisiaca (banana) & $\sqrt{ }$ & $\sqrt{ }$ & $\sqrt{ }$ \\
\hline Opuntia ficus-indica (prickly pear) & & $\sqrt{ }$ & \\
\hline Persea americana (avocado) & $\sqrt{ }$ & $\sqrt{ }$ & $\sqrt{ }$ \\
\hline Phaseolus vulgaris (beans) & $\sqrt{ }$ & $\sqrt{ }$ & \\
\hline Pisum sativum (peas) & $\sqrt{ }$ & $\sqrt{ }$ & \\
\hline Prunus armeniacum (apricots) & $\sqrt{ }$ & & \\
\hline Prunus persicum (peaches) & $\sqrt{ }$ & & \\
\hline Psidium guajava (guava) & $\sqrt{ }$ & & \\
\hline Solanum tuberosum (potato) & $\sqrt{ }$ & $\sqrt{ }$ & \\
\hline Sonchus asper (spiny sowthistle) & $\sqrt{ }$ & & \\
\hline Spinacia oleracea (spinach) & $\sqrt{ }$ & $\sqrt{ }$ & $\sqrt{ }$ \\
\hline Vitis vinifera (grapes) & $\sqrt{ }$ & $\sqrt{ }$ & \\
\hline Zea mays (maize) & $\sqrt{ }$ & & \\
\hline
\end{tabular}

Table 5. Household's perceptions on the value of home gardens in the study area

\begin{tabular}{lc}
\hline Variable & $\begin{array}{c}\text { Proportion } \\
(\%)\end{array}$ \\
\hline $\begin{array}{l}\text { Provision of food to the household } \\
\text { Home garden produce usually insufficient for the }\end{array}$ & 83.7 \\
$\begin{array}{l}\text { household } \\
\text { Reduction of household expenditure on food }\end{array}$ & 24.0 \\
$\begin{array}{l}\text { bought from the market } \\
\text { A diversity of edible plant species grown and }\end{array}$ & 20.2 \\
$\begin{array}{l}\text { managed in home gardens } \\
\text { yearsible to have garden produce throughout the }\end{array}$ & 17.8 \\
$\begin{array}{l}\text { Home garden produce important to reduce levels of } \\
\text { poverty and inequalities }\end{array}$ & 13.2 \\
$\begin{array}{l}\text { Importance of home gardening has decreased } \\
\text { Home garden produce important for the health of } \\
\text { the family }\end{array}$ & 10.1 \\
\hline
\end{tabular}

To conclude, results of this study corroborate observations made by Galhena et al. (2013) that the most important social benefit of home gardening activities is the direct contributions to food security of the families, enabling households to increase food availability, 
accessibility and utilization. Home gardens enable resource-poor and marginalized families to produce a yearround supply of diverse food plants needed for creating and maintaining sustainable food security for the household without requiring large capital investments. The central role of home gardens as sources of food plants and other related uses in the study area is unlikely to diminish in the near future. Utilization of home gardens as food sources leads to food security and sovereignty of the family, leading to poverty alleviation and reducing food inequalities within a household. The importance of home gardens as food sources needs to be valued by scientists, government policymakers, and agriculturalists responsible for agricultural policy, extension activities, and research. Therefore, there is a need to include management of home gardens in rural areas of South Africa in the agricultural development and research agenda as this agricultural system has potential in enhancing food security.

\section{ACKNOWLEDGEMENTS}

This work was supported by the Govani Mbeki Research and Development Centre, University of Fort Hare, South Africa. Keith Obose, Thabo Ntabeni and Philisa Siyikile assisted with fieldwork and data gathering.

\section{REFERENCES}

Abdoellah OS, Schneider M, Nugraha LM, Suparman Y, Voletta CT, Withaningsih S, Parikesit A, Heptiyanggit A, Hakim L. 2020. Home garden commercialization: Extent, household characteristics, and effect on food security and food sovereignty in rural Indonesia. Sustain Sci 15: 797-815. DOI: 10.1007/s11625-020-00788-9.

Adekunle, O. O. (2013). The role of home gardens in household food security in Eastern Cape: A case study of three villages in Nkonkobe Municipality. J Agric Sci 5 (10): 67-76. DOI: 10.5539/jas.v5n10p67.

Algert S, Diekmann L, Renvall M, Gray L. 2016. Community and home gardens increase vegetable intake and food security of residents in San Jose, California. California Agric 70: 77-82. DOI: 10.3733/ca.v070n02p77.

Allen T, Prosperi P, Cogill B, Flichman G. 2014. Agricultural biodiversity, social-ecological systems and sustainable diets. Proc Nutr Soc 73: 498-508. DOI: 10.1017/S002966511400069X.

Atyosi Z, Ramarumo LJ, Maroyi A. 2019. Alien plants in the Eastern Cape province in South Africa: Perceptions of their contributions to livelihoods of local communities. Sustainability 11: 5043. DOI: $10.3390 / \mathrm{su} 11185044$.

Buchmann C. 2009. Cuban home gardens and their role in socialecological resilience. Human Ecol 37: 705-721. DOI 10.1007/s10745-009-9283-9.

Chambers R. 1994. The origins and practice of participatory rural appraisal (PRA). World Dev 22: 953-969. DOI: 10.1016/0305 750X(94)90141-4.

Cindi F. 2018. The Rise and Fall of the Ciskei Homeland and Bantustan Leadership, 1972-1994. Oral Hist J South Africa 6: 1-8. DOI: 10.25159/2309-5792/3971.

Cornwall A, Pratt G. 2011. The use and abuse of participatory rural appraisal: Reflections from practice. Agric Human Values 28: 263 272. DOI: $10.1007 / \mathrm{s} 10460-010-9262-1$

Di Falco S. 2012. On the value of agricultural biodiversity. Ann Rev Resour Econ 9: 207-223. DOI: 10.1146/annurev-resource-110811114543.

Etikan I, Alkassim R, Abubakar S. 2015. Comparison of snowball sampling and sequential sampling technique. Biometric Biostatistics Intl J 3: 1-2. DOI: 10.15406/bbij.2015.03.00055.
Fernandes ECM, Nair PKR. 1986. An evaluation of the structure and function of tropical home gardens. Agric Syst 21: 279-210. DOI: 10.1016/0308-521X(86)90104-6.

Freedman RI. 2015. Indigenous wild food plants in home gardens: Improving health and income with the assistance of agricultural extension. Intl J Agric Ext 3: 63-71. DOI: 10.2256/1123-56-8.

Galhena DH, Freed R, Maredia KM. 2013. Home gardens: A promising approach to enhance household food security and wellbeing. Agric Food Sec 2: 8. DOI: 10.1186/2048-7010-2-8.

Gray L, Guzman P, Glowa KM, Drevno AG. 2014. Can home gardens scale up into movements for social change? The role of home gardens in providing food security and community change in San Jose, California. Local Environ 19: 187-203. DOI: 10.1080/13549839.2013.792048.

Hamann M, Tuinder V. 2012. Introducing the Eastern Cape: A quick guide to its history, diversity and future challenges. Stockholm Resilience Centre, Stockholm University, Stockholm, Sweden.

Heckathorn DD. 2011. Snowball versus respondent-driven sampling. Sociol Method 41: 355-366. DOI: 10.1111/j.1467-9531.2011.01244.x

Heywood VH. 2013. Overview of agricultural biodiversity and its contribution to nutrition and health. In: Hunter D, Borelli T, Mattei F, Fanzo J (eds). Diversifying Food and Diets using Agricultural Biodiversity to Improve Nutrition and Health, Earthscan, London, UK.

Jari B, Fraser GCG. 2012. Influence of institutional and technical factors on market choices of smallholder farmers in the Kat River Valley. In: Van Schalkwyk HD, Groenewald JA, Fraser GCG, Obi A, Van Tilburg A (eds.). Unlocking markets to smallholders: Lessons from South Africa. Wageningen Academic Press, Wageningen, Netherlands.

Khanal S, Khanal D, Kunwar B. 2019. Assessing the structure and factors affecting agrobiodiversity of home garden at Katahari rural municipality, province 1, Nepal. J Agriculture and Environment 20: 129-143. DOI: 10.3126/aej.v20i0.25039.

Lowe WAM, Sinniah J, Jeyavanan K, Silva GLLP, Pushpakumara DKNG. 2021. 'Can homegardens assist in enhancing the domestic food security?' A study in Jaffna Peninsula, Sri Lanka. Agrofor Syst 95: 1205-1216. DOI: 10.1007/s10457-021-00647-1.

Manyevere A, Muchaonyerwa P, Laker MC, Mnkeni PNS. 2014. Farmers' perspectives with regard to crop production: An analysis of Nkonkobe municipality, South Africa. J Agric Rural Dev Trop Subtrop 115: 41-53. DOI: 10. 34-2014020344887.

Maroyi A. 2020. Ethnobotanical study of wild and cultivated vegetables in the Eastern Cape province, South Africa. Biodiversitas 21: 39823989. DOI: 10.13057/biodiv/d210908.

Maroyi A. 2017a. Diversity of use and local knowledge of wild and cultivated plants in the Eastern Cape province, South Africa. J Ethnobiol Ethnomed 13: 43. DOI: 10.1186/s13002-017-0173-8.

Maroyi A. 2017b. Assessment of Useful Plants in the Catchment Area of the Proposed Ntabelanga Dam in the Eastern Cape Province, South Africa. Sci World J 2017: 3763607. DOI: 10.1155/2017/3763607

Maroyi A. 2013. Use and management of home garden plants in Zvishavane District, Zimbabwe. Trop Ecol 54: 191-203. DOI: 10.1050/1533.2013.213452.

Mdweshu L, Maroyi A. 2020a. Local perceptions about utilization of invasive alien species Opuntia ficus-indica in three Local Municipalities in the Eastern Cape province, South Africa. Biodiversitas 21: 1653-1659. DOI: 10.13057/biodiv/d210446.

Mdweshu L, Maroyi A. 2020b. Local ecological knowledge of invasive alien species Opuntia ficus-indica in three Local Municipalities in the Eastern Cape province, South Africa. Ecol Environ Conserv 26: 457466. DOI: $10.10234 / 423736$.

Mehari AB, Abera MW. 2019. Opportunities and challenges of adopting home garden agroforestry practices in Ethiopia. Cogent Food Agric 5: 11618522. DOI: 10.1080/23311932.2019.1618522.

Menconi ME, Grohmann D, Mancinelli C. 2017. European farmers and participatory rural appraisal: A systematic literature review on experiences to optimize rural development. Land Use Pol 60: 1-11. DOI: 10.1016/j.landusepol.2016.10.007.

Mitchell R, Hanstad T. 2004. Small homegarden plots and sustainable livelihoods for the poor. LSP Working Paper 11, Rome, Italy.

Molebatsi LY, Siebert SJ, Cilliers SS, Lubbe CS, Dovoren NE. 2010. The Tswana tshimo: A homegarden system of useful plants with a specific layout and function. Afr J Agric Res 5: 2952-2963. DOI: 10.5897/AJAR2010.2001. 
Mubarak EA, Suwardi AB. 2020. The fruit plant species diversity in the home gardens and their contribution to the livelihood of communities in rural area. Biodiversitas 21: 3670-3675. DOI: 10.13057/biodiv/d210833.

Musemwa L, Muchenje V, Mushunje A, Aghdasi F, Zhou L. 2015. Household food insecurity in the poorest province of South Africa: level, causes and coping strategies. Food Sec 7: 647-655. DOI: 10.1007/s12571-015-0422-4

Musvoto C, Campbell BM. 1995. Mango trees as components of agroforestry systems in Mangwende, Zimbabwe. Agrofor Syst 32 247-260. DOI: 10.1007/BF00711713.

Nell W, Wessels B, Mokoka J, Machedi S. 2000. A creative multidisciplinary approach towards the development of food gardening. Dev Southern Africa 17: 807-819. DOI 10.1080/03768350020013642.

Nemudzudzanyi AO, Siebert SJ, Zobolo AM, Molebatsi LY. 2009. The Zulu muzi: A home garden system of useful plants with a specific layout and function. Afr J Indigenous Knowl Syst 9: 57-72. DOI: 10520/EJC61583.

Ngcaba P, Maroyi A. 2017. Floristic composition and diversity in Tsitsa river catchment area, the Eastern Cape province, South Africa. J Biol Sci 17: 288-297. DOI:_10.3923/jbs.2017.288.297.

Paumgarten F, Shackleton CM, Cocks ML. 2005. Growing of trees in homegardens by rural households in the Eastern Cape and Limpopo provinces, South Africa. Int J Sustain Dev World Ecol 12: 1-19. DOI $10.1080 / 13504500509469647$.
Popoola OO, Yusuf SFG, Monde N. 2020. South African national climate change response policy sensitisation: An assessment of smallholder farmers in Amathole District Municipality, Eastern Cape Province. Sustainability 12: 2616. DOI: 10.3390/su12072616.

Sukeri K, Alonso-Betancourt O, Emsley R. 2014. Lessons from the past: Historical perspectives of mental health in the Eastern Cape. South Afr J Psychiatry 20: 34-39. DOI: 10.7196/SAJP.568.

Thinyane Z, Maroyi A. 2019. Non-timber forest products (NTFPs): A viable option for livelihood enhancement in the Eastern Cape Province, South Africa. J Biol Sci 19: 248-258. DOI: 10.3923/jbs.2019.248.258.

Thrupp LA. 2000. Linking agricultural biodiversity and food security: the valuable role of agrobiodiversity for sustainable agriculture. Intl Affairs 76: 265-281. DOI: 10.1111/1468-2346.00133.

Van Averbeke W, Khosa TB. 2007. The contribution of smallholder agriculture to the nutrition of rural households in a semi-arid environment in South Africa. Water SA 33: 413-418. DOI: 10.4314/wsa.v33i3.49158.

Waters J. 2015. Snowball sampling: a cautionary tale involving a study of older drug users. Intl J Soc Res Method 18: 367-380. DOI: 10.1080/13645579.2014.953316.

Westaway A. 2012. Rural poverty in the Eastern Cape Province: Legacy of apartheid or consequence of contemporary segregation?. Dev Southern Africa 29: 115-125. DOI: 10.1080/0376835X.2012.645646. 